\title{
THE BASIC NEEDS APPROACH TO DEVELOPMENT: THE QUESTION OF EDUCATION FOR BLACK PEOPLE IN NATAL
}

\section{Dulcie Krige}

CSDS Working Paper No. 1

CENTRE FOR SOCIAL AND DEVELOPMENT STUDIES 
THE BASIC NEEDS APPROACH TO DEVELOPMENT:

THE QUESTION OF EDUCATION FOR BLACK PEOPLE IN NATAL

Dulcie Krige

Centre for Social and Development Studies

University of Natal

Durban

1990

CSDS Working Paper No. 1 
The Centre for Social and Development Studies was established in 1988 through the merger of the Centre for Applied Social Science and the Development Studies Unit. The purpose of the centre is to focus university research in such a way as to make it relevant to the needs of the surrounding developing communities, to generate general awareness of development problems and to assist in aiding the process of appropriate development planning.

The financial assistance of the Institute for Research Development of the Human Sciences Research Council towards this research is hereby acknowledged. Opinions expressed in this publication and conclusions arrived at are those of the author and are not necessarily to be attributed to the Institute for Research Development or the Human Sciences Research Council.

ISBN NO: 0-86980-711-0 


\section{THE BASIC NEEDS APPROACH TO DEVELOPMENT: THE QUESTION OF EDUCATION FOR BLACK PEOPLE IN NATAL 1}

\section{THE BASIC NEEDS APPROACH}

The realization that even when the gross national product per capita increased in developing countries, the income gap generally widened, gave rise to the 'basic needs' approach to development. This approach is directed at the removal of mass deprivation and is based on the availability of consumption needs such as nutrition, housing, clothing and basic public services such as health, sanitation, potable water, education and transport. Employment is often included because of its role in facilitating access to personal consumption needs, and political participation because of its role in improving access to all the other basic needs. ${ }^{2}$

In a research project which examines access to basic needs of blacks in $\mathrm{Natal}^{3}$, the question of the provision of education was one of the primary aspects examined. While this particular study focused on blacks in Natal it is recognized that the interpenetration of Natal and KwaZulu necessitates viewing them as a unified whole. It is envisaged that research proposals now under consideration will make this possible. The present study is essentially a preliminary investigation.

\section{CONTROL OVER BLACK EDUCATION IN NATAL}

Black education in Natal falls under the Department of Education and Training, (DET - the education authority for blacks in all areas outside the homelands). In Natal it is organized into seven circuits (Durban, Vryheid, Glencoe, Pietermaritzburg South, Pietermaritzburg West, Piet Retief ${ }^{4}$ and Ermelo, the latter two of which are in fact in the Transvaal) under the direction of the Regional Office in Pietermaritzburg.

The provision of educational facilities in Natal census districts ${ }^{5}$ is complicated however by the presence of $134 \mathrm{KwaZulu}$ administered schools in Natal census districts ${ }^{6}$. DET Regional Office firmly maintains that these are on South African Development Trust land (SADT) or black freehold land. The difficulty in obtaining precise information regarding South African Development Trust land makes this impossible to verify but certainly these schools are in areas included in Natal in the 1985 Census $^{7}$ and the 
population of these areas was enumerated as being in Natal. For comparative purposes (comparing school enrollment to population numbers), therefore, it is necessary to bear this complication in mind. The main text of this article refers solely to the DET schools but reference to the KwaZulu schools in Natal census districts will be footnoted where necessary.

\section{TYPES OF SCHOOLS}

\subsection{State-gided schools}

The vast majority of black schools in Natal (619 out of the total of 759 i.e. 80 per cent $)^{8}$ are farm schools. ${ }^{9}$ A further 11 are private schools, 1 a factory school, 6 hospital schools, 9 mine schools and 9 scheduled schools. ${ }^{10}$ These schools are erected on the initiative of a farmer (or mine or hospital) and thus the decision as to their location is not that of DET. ${ }^{11}$ The school buildings are erected by the farmer and, if they are according to Departmental specifications, he may claim a subsidy up to R6 $000^{12}$. The farmer has jurisdiction over who attends his school and may limit it to the children of his own employees or may allow neighbouring children to use it. Although he guarantees 13 to continue the school when he is paid (in part) for its erection by the Department, if the farm is sold the new owner is not bound by this guarantee and is free to close down the school. Half the farm schools go up to Standard one ${ }^{14}$ or two and most of the remainder to Standard three or Standard four, with a few up to Standard five.

\subsection{State schools}

State schools 15 are fully funded and planned by the Department of Education and Training i.e. buildings as well as staff salaries. One hundred and five of the 759 schools are of this type. The important factor here is that it is DET in this instance which decides where the school is located and the school cannot arbitrarily be closed by persons outside the Department. These schools were not necessarily built by the Department; they could be mission schools for example taken over by the Department.

\section{ACCESS TO EDUCATIONAL INSTITUTIONS ${ }^{16}$}

An important aspect of access to basic needs is the spatial access to services such as educational institutions. For this reason the areas within 5 kilometres of a DET junior 
primary school and 10 kilometres of a DET primary school were mapped. Since a map showing the population aged 5-15 in each enumerator sub district of the 1985 census had already been prepared it was possible to estimate the percentage of the school going population within 5 kilometres of a junior primary school and within 10 kilometres of a primary school. 17

\subsection{Access to junior primary schools}

Map 3 shows areas within a 5 kilometre radius of a junior primary school (Class 1 to Standard 2). Since many farm schools fall into this category the coverage is fairly reasonable throughout much of Natal with 75 per cent of the population aged 5-15 years falling within this radius ( 88 per cent of the urban population and 72 per cent of the rural population - see Tables 1 and 2)..$^{18}$

\subsection{Access to Primary Schools}

Map 4 shows the areas which are within 10 kilometres of a primary school (from Class 1 to Standard 5). A 10 kilometre walk to and from school daily is, of course, a very long way. Thus it is not implied here that those within 10 kilometres are well provided for, but that those beyond 10 kilometres are very poorly provided for indeed - that there realiy should not be any such areas on the map. This distance is the absolute limit of acceptability and areas where the school-going population is further than 10 kilometres from a school are areas where urgent steps need to be taken. This is based in part on DETs own assessment in the 'Provision of Education for Black Pupils in Rural Areas' (DET, 1986, p. 83) that the fact that 'large numbers of pupils in sparsely populated areas must walk 10-15 kilometres to school each day is unacceptable'. There are indications from case studies that, in some areas, as many as a quarter of the secondary school pupils walk over 12 kilometres to and from school each day. ${ }^{19}$ It would appear that a comprehensive survey of distances travelled to school each day is urgently necessary.

Twenty-three per cent of the population aged 5-15 years live further than 10 kilometres from the nearest primary school (see Table 1), a serious impediment indeed to improved schooling in Natal. Urban areas, with only one per cent living further than 10 kilometres from a primary school, ${ }^{20}$ are clearly greatly advantaged compared to rural areas where 32 per cent live beyond this distance. 21 The benefits of urban residence are clearly highlighted. 
A recent statement by the deputy minister of education Mr Sam de Beer (South African Institute of Race Relations Social and Economic Update, No. 5, p. 18) indicated the desire of DET to locate schools within 5 kilometres of all pupils; and to include standards 6 and 7 in rural primary schools where a secondary school is not readily accessible. This would necessitate a major school building and expansion programme in Natal since:

a) Map 4 shows areas within 10 kilometres of a primary school. In order to indicate 5 kilometre access the hatched circles would need to shrink to the size they are in Map 3 and there would be large areas without the desired access.

b) The relatively sparse distribution of black children in parts of rural Natal would result in small schools which would mean that new and innovative solutions would need to be considered. If such solutions must exclude non-racial schools they would certainly need to consider such things as a biennial school intake (Class 1 intake only every second year) or multigrade classes (two or more levels taught by the same teacher in the same classroom) as elsewhere in Africa (Gould, 1982, p. 44-8)

c) The decision as to where to locate rural schools would need to be made by DET and not by farmers; and a solution would need to be arrived at regarding the problem of ownership of school land in rural areas. Schools would need to be entirely under the control of DET since if they are controlled by a farmer he can decide which children to admit.

d) The vast majority of secondary schools are at present in urban areas (see 4.3); thus to provide access to Standard 6 and Standard 7 for all rural black children would require a major expansion of classrooms and provision of secondary teachers (who are specialist teachers unlike the general teachers required at primary level and hence teach only one or two subjects. Perhaps a more general training for junior secondary teachers would need to be instituted at training colleges to meet the needs of these small rural secondary classes).

\subsection{Access to secondary schools}

Of the 771 DET schools in Natal only 25 are secondary schools and seven are 
junior secondary schools. A further twenty seven primary schools have a junior secondary section attached to them. Overall in Natal (see Table 3) there were 17825 secondary level scholars compared to 113479 primary scholars (i.e. secondary enrollment was 14 per cent of total enrollment) in 1985.22 The opportunities for a secondary education, for a primary school leaver, are therefore, very restricted. Spatial access to secondary education is particularly severely restricted in certain areas. There is no secondary education at all in 10 census districts ${ }^{23}$ and in a further fourteen districts secondary education does not reach as far as Standard 10.24

The secondary and junior secondary schools are situated almost entirely in urban areas (with the exception of Lower Umfolosi and the densely settled area of Mpolweni in New Hanover). However, twenty two primary schools in rural areas have a standard 6 and 7.25

\section{NUMBER OF CHILDREN IN SCHOOL}

Although the difficulties of spatial access to schooling give part of the picture of education as a basic need it is of interest to examine the number of children actually in school compared to the population of school-going age per census district ${ }^{26}$ (see Table 3 ). The problem here is the range of ages in any particular standard in black schools which means that it is impossible to compare accurately the enrollment at primary school or at secondary school with the corresponding age group in the 1985 census. $^{27}$ In fact, however, since in many census districts there are no secondary schools, this question is somewhat academic. The number of primary school pupils is often the same as the number of pupils overall. The number of black pupils in Natal schools up to Standard 5 is equivalent to 48 per cent ${ }^{28}$ of the 5-15 age group. 29 Thus, although 74 per cent of the 5-15 year age group is within 10 kilometres of a primary school, only some 48 per cent actually attend school. This indicates the importance of other intervening variables, not least, particularly in urban areas, the numerical limit on the number of pupils a school can accept ${ }^{30}$ and in rural areas the demand by farmers for child labour ${ }^{31}$ (see Nassan, 1988, p. 33). Other difficulties preventing school attendance include topography (rivers or hilly terrain) and poverty (the child's labour is needed at home, or uniforms and fees cannot be afforded). The major impediment, however, is clearly the fact that the majority of farm schools go only as far as Standard 2, so that access to a primary school beyond this level is virtually impossible for many children. 


\section{SECONDARY SCHOOL ENROLLMENT AS A PERCENTAGE OF SCHOOL GOING POPULATION FOR BLACKS IN KWAZULU AND THE RSA AS A WHOLE}

E.G. Malherbe $(1977$, p. 269) in his seminal work on education in South Africa noted that "...the proportion of the population receiving post-primary education...(is)...the best single index of educational progress in a developing country'. He found that in 1973 (1977, p. 275) secondary level scholars formed 36 per cent of the white school going population and 11 per cent of the black. In more recent years the ratio has changed somewhat.

- in 1986 secondary scholars formed 19 per cent of the scholars in DET schools (throughout RSA) (RIEP, 1986, p. 23-8).

in Natal in 1985 secondary scholars formed 14 per cent of the scholars in DET schools (this study).

secondary scholars formed 19 per cent of the total KwaZulu scholars in 1985 (The KwaZulu Department of Economic Affairs, 1987, p. 15).

in the National States as a whole in 1986 secondary scholars formed 22 per cent of total enroliment (RIEP, 1986, p. 23-8).

among RSA whites in 1986 secondary scholars formed 42 per cent of total scholars (RIEP, 1986, p. 23-8).

among Natal whites the percentage formed by secondary scholars was 43 per cent (RIEP, 1986, p. 23-8).

It is evident, therefore, that the provision of secondary education by DET in Natal lags behind that of both KwaZulu and that of DET in RSA as a whole. All of these, moreover, are very inadequately provided with secondary facilities compared to whites in South Africa. It must be borne in mind, however, that the number of black scholars in the RSA as a whole sitting the Standard 10 exam has increased from 82815 to 151232 between 1985 and 1987. The number passing the exam has more than doubled and those attaining a matriculation exemption has increased two and a half times between 1985 and 1987 . This 
indicates a substantial increase in secondary school facilities. Whether this recent improvement was also experienced in DET schools in Natal has yet to be investigated.

\section{PERCENTAGE OF THE 20-24 AGE COHORT WHO HAVE RECEIVED SOME SECONDARY EDUCATION}

Thus far an analysis has been made of the percentage of children in school, the percentage in the secondary phase and the percentage with reasonable access. It is now of interest to turn to the end result of this process and to see how many of those, in the age group that has most recently finished school, have acquired an adequate education. Table 4 shows the numbers and percentages, per census district, of those who have a Standard 1 education or less, a Standard 2-5 education and a secondary education (not necessarily complete). ${ }^{32}$

This section is based on unpublished figures from the 1985 census made available by Central Statistical Services. This data is particularly important from the perspective of basic needs since it examines the end product of the provision of education i.e. how effective the availability of facilities has been.

There is a certain but not exact correspondence between the census districts

a) lacking secondary school facilities and

b) those where a low percentage (20 per cent or less) of the 20-24 age cohort have a secondary education. Clearly, people either move to other areas or simply cross boundaries daily in order to attain a secondary education (possibly into relatively accessible KwaZulu areas) or move elsewhere after completing their education in order to obtain employment. The fact that the highest percentage of those with a secondary education are in Pietermaritzburg, Durban and Pinetown is to be expected from the employment opportunities these areas present, but tells us little about whether the secondary education was obtained in these areas or not (although it should be noted that they are the areas with the best secondary school facilities). It seems likely that migration of the better educated from rural areas is an important factor and that rural areas, small urban centres and KwaZulu may subsidize urban areas in terms of the provision of education. 33 
Only 30 per cent of those in the 20-24 age cohort (51 per cent of those in urban areas and 19 per cent of those in rural areas) have any secondary schooling whatsoever. 34 This has very important policy implications since:

a) This is the age cohort newly arrived on the job market with, it can be expected, a better educational background than older cohorts. It would seem, therefore, that where secondary education is particularly lacking, these would be areas eminently suitable for the provision of adult education facilities. The recognition that any form of skilled labour requires at least some secondary education makes this an urgent consideration since it is really only at the secondary level that children attending black schools could be regarded as functionally literate (see the second footnote of 3.1).

b) More important, however, is the relevance of this percentage as far as women are concerned. 35 The percentage of women of child-bearing age with a secondary education is particularly crucial in the light of the finding of the World Fertility Survey (Cleland, 1985, p. 278 \& 291) that there is a link between mother's education and a decline in both fertility and infant mortality rates ${ }^{36}(1985$, p. 291$)$. From this it would appear that for a rapid decline in fertility and a marked decrease in infant mortality to occur the post-primary education of girls is a major influencing factor. This indicator thus assumes great significance with regard to both birth rates and infant mortality (an important indicator of the overall wellbeing of a population).

\section{EDUCATIONAL QUALIFICATIONS OF THE BLACK POPULATION IN NATAL COMPARED TO OTHER RACE GROUPS IN NATAL AND TO BLACKS IN KWAZULU AND IN SOUTH AFRICA AS A WHOLE.}

Having looked at the education qualifications of a particular black age cohort and the difference in provision of secondary education it is of interest to turn briefly to the broader picture of the educational qualifications of the various 'race' groups in Natal in order to assess the position of blacks in relation to other groups in Natal and to blacks in KwaZulu, ${ }^{37}$ (see Table 6) ${ }^{38}$. While only 13 per cent of whites in Natal have no education ${ }^{39}$ ( 18 per cent of 'coloureds' and 20 per cent of Indians), 43 per cent of blacks in Natal have no education (compared to 40 per cent of blacks in KwaZulu 40 and 37 per cent of blacks in the Republic of South Africa and the non-independent homelands). There is clearly a discrepancy here which, as the previous data shows, is not being attended to 
speedily enough. While the educational deprivation of adults can only be corrected by adult education and literacy campaigns, the previous analysis in this report shows that too few children have adequate access to education even now. 41

At the other end of the scale, while 21 per cent of Natal whites have a Standard 10 qualification ${ }^{42}$ ( 5 per cent of Natal 'coloureds', and 9 per cent of Natal Indians) a mere 1,4 per cent of Natal blacks have this level of education. Two per cent of KwaZulu blacks have a Standard 10 education and 1,9 per cent of blacks in the Republic of South Africa and the independent homelands, showing that Natal compares somewhat unfavourably even with these groups.

\section{FUTURE PROSPECTS}

There is clearly concern on the part of all involved, not least officials of DET, regarding the need for increased provision of school facilities and for improved spatial access (DET, 1986, p. 83). It is a major problem for improved education that in remote, sparsely populated areas children of different 'races' cannot share education facilities. If this must be accepted at the present time then clearly other innovative solutions must be found. There has been talk of assessing the possibility of 'bussing' children to school. This needs investigation as there are some fairly densely settled areas which would benefit. Very remote areas with scattered populations and poor roads might need other solutions however. Gould (1982, p. 44-8) working on dispersed populations in other parts of Africa where exactly the same problems occur, suggests that small multigrade schools, or a biennial school intake, may be ways of ameliorating the problem. It would seem essential, however, that schools become entirely a state responsibility since the decision where to locate a school, who should attend it, and what level it should go up to, should be the responsibility of DET and not of an individual farmer as is the case at present at farm schools.

\section{CONCLUSION}

It would appear therefore, with regard to the availability of education as a basic need, that:

1. education of blacks in Natal is inadequate compared not only to that whites, 'coloureds' and Indians, but also of blacks in KwaZulu and elsewhere in the Republic of South Africa on the basis of - 
- percentage of children enrolled at school.

* the higher percentage of blacks in Natal with no education and the lower percentage with Standard 10.

- lower secondary school enrollment as a percentage of school enrollment.

2. in order to reach the goal stated by DET of no more than a 5 kilometre walk for primary school children it will be necessary to -

- build large numbers of schools in rural areas.

- reconsider the question of farm schools,

- investigate multigrade classes

3. secondary school facilities need to be greatly increased (indeed instituted) in most rural areas of Natal.

4. the lack of secondary school qualifications of black adults, imperative for an increase in literacy and for a lowering of the infant mortality rate and the birth rate, urgently necessitates the provision of adult education facilities.

5. the fact that most schools are farm schools prevents DET making rational decisions regarding the location of schools.

6. the urban bias in education provision, particularly regarding secondary school facilities, must be lessened.

7. the fact that black schooling in Natal is in part provided by KwaZulu needs to be acknowledged together with the difficulty of separating, for analytic purposes, the education provision between Natal and KwaZulu.

NOTES:

1 The financial assistance of the Institute for Research Development of the Human Sciences Research council towards this research is hereby acknowledged. Opinions expressed in this publication and conclusions arrived at, are those of the author and are not necessarily to be attributed to the Institute for Research 
Development or the Human Sciences Research Council.

A very similar paper appeared as an article in Development Southern Africa Vol. 6, No. 2 May 1989.

The co-operation and assistance of Central Statistical Services and the Department of Education and Training is gratefully acknowledged.

The term 'blacks' in this report excludes Indians and so-called 'coloureds'.

While the primary intention is the improvement in the quality of life of the poor, 'basic needs' is not, in fact, a welfare concept since increased productivity, which is of great importance to the overall economy, may be influenced by improved education and health.

Although the basic needs approach to development has many proponents (Streeten 1981, Nattrass 1979) it also attracts much criticism (Sandbrook 1982). This debate cannot be included in a brief article and this paper is based on the premise that improved access to education is a 'good' to which all people would aspire and are entitled. It does not address the controversial question of the content of education nor of the discriminatory funding of education for the various 'race' groups in South Africa.

3 Maps at a scale of 1 in a million showing the distribution of black population in Natal by enumerator sub district in the 1985 Census (for 0-4 years, 5-15 vears, pensionable age, and total) and the location of schools, clinics, hospitals, roads and railways are sold by the Centre for Social and Development Studies at the University of Natal, Durban.

The magisterial district of Paul Pietersburg (in Natal) is however in the Piet Retief circuit.

As in the 1985 census. Census districts closely approximate magisterial districts but are not always identical.

See Map 1 for census district boundaries.

7 Some SADT areas are included in KwaZulu in the 1985 census (e.g. Inanda Released Area 33) and others in Natal (e.g. Western Babanango).

8 These figures reflect the situation in 1985. The Ermelo and Piet Retief circuits have been excluded, since they are outside Natal, but Paulpietersburg in the Piet Retief circuit has been included.

9 The percentage of scholars attending farm schools would be lower than 80 per cent however since farm schools are often fairly small.

10 A scheduled school is a state-aided school on land not owned by DET. It is extremely difficult to get a definition of these schools from the DET but it would appear that 'scheduled' schools do not get any building subsidy from the Department of Education and Training. It appears likely that this inability to obtain a building subsidy also applies to factory, hospital and mine schools. In fact it has been found that in parts of Lower Tugela the situation is extremely complex and many of the schools classified as farm schools are not in fact run by farmers but are run, for instance, by missions on former mission land which has been sold to private farmers.

11 Teachers salaries are paid once the school is registered and included in the budget. Managers (i.e. farmers) appoint teachers - the Department can only refuse to pay the salary. 
Ardington (1989, p. 50) notes that In late 1988 new regulations for the subsidization of rural education were introduced. In general 75 per cent of the value of a building (as estimated by technical officials of the department) may be claimed and will be paid out if funds permit. An official of the department stated that when allocating funds preference would be given to claims for classrooms and toilets, so that, although teacher accommodation has officially been placed on the same footing as classroom accommodation in terms of the subsidy, in view of the history of the shortage of funds required to meet classroom susidization it would seem unlikely that a significant number of loans will be made for accommodation unless the budget is substantially increased'.

He is obliged to keep the school open for ten years or refund a pro rata share of the subsidy he receives.

Zuvekas (1979, p. 153) notes that 'Functional literacy usually is attained only after three to four years of schooling and even then is maintained only if used'. This level of literacy would only permit extremely simple reading and writing (e.g. name and address) and a much higher level would be necessary for adequate literacy as part of the workforce. The question of the level of schooling necessary for literacy, particularly in rural black schools, is a much debated and contentious one. In many cases a completed primary school education would be necessary for even functional literacy. A recent HSRC publication (van der Kooy, 1988, p. 92) would certainly count a person with four years of schooling or less as illiterate.

It should be noted, (see Map 2) that almost all these schools are in urban areas (Lamontville, Chesterville, Klaarwater - St Wendolins, Sobantu, Imbali, Vryheid, Glencoe, Dundee, Bulwer, Greytown, Bruntville, Ladysmith, Howick, Hlabisa, Weenen, Matatiele, Cedarville, Kokstad, Tongaat, Stanger, Shakaskraal, Louwsburg and Bergville). These are, of course, the areas in which there can be no farm schools so they are clearly areas towards which DET must direct its attention. Furthermore, DE $\Gamma$ can only establish schools in areas in which it can obtain land i.e. in black townships administered by the Natal Provincial Administration's Department of Community Services. The fact that urban areas are also the ones with the most vocal demands for education must play its part.

There are various rural areas, particularly SADT areas, where there are fairly large numbers of state schools - these include western Babanango (5), and the northern section of interior Lower Umfolosi (6) as well as the Mpolweni area of New Hanover (5). Apart from these rural schools there are some 13 scattered rural, state, primary schools. In the peri-urban areas of Inanda, (the SADT area of Released Area 33), the Department has constructed a number of schools(four primary, one junior secondary and one secondary) since this area, long scheduled to become part of KwaZulu, has suffered trom a severe lack of facilities (educational and otherwise) for many years. There are also schools in the areas included in KwaZulu in the 1985 census - four in Emnambithi and one each in Nkandla and Hlanganani. These appear to be on SADT land which will be incorporated into KwaZulu in due course.

16 The co-operation of DET circuit inspectors, with the permission of the Regional Office, in mapping the location of schools is gratefully acknowledged.

17 The fragmentation and spatial interpenetration of Natal and KwaZulu makes access to KwaZulu schools on or near the border possible in many parts of Natal. If such areas are taken into account in those areas where DET schools are lacking, the percentage within 5 kilometres of a junior primary is increased from 75 per cent to 89 per cent overall, and those within 10 kilometres of a primary school from 74 per cent to 94 per cent. These percentages would make it appear that 
KwaZulu schools could make a substantial difference to accessibility to school for a black child in Natal. The extent to which children in fact cross into KwaZulu from Natal is not known. There are reports, which it has not been possible to verify, that the DET will not accept a child who has previously attended a KwaZulu school and, similarly, that KwaZulu will not accept a child who has attended a DET school. If these reports are true (and how strictly such a ruling would be applied is likely to change under different circumstances) it would probably be the only way of controlling children crossing borders to attend school since it is very easy indeed to lie about the exact location of one's home but more difficult to change a school transfer card.

Pinetown, Lion's River, New Hanover, Mooi River and Lower Umfolosi have over 90 per cent of the rural children within 5 kilometres of a junior primary school. There is a great variation between census districts however, with five having over 90 per cent of the rural population with this level of access, and six with fewer than half of the potential rural scholars within 5 kilometres of a junior primary school. Polela, Impendle, Weenen, Eshowe, Mtonjaneni and Mtunzini have under 50 per cent of rural children within 5 kilometres of a junior primary school.

Personal communication regarding a study done in the Vryheid district.

This section is based on spatial accessibility of schools. It does not take into account the areas where there are too many potential scholars to be catered for by the available schools, as would appear to be the case in many urban areas.

21 The variation between census districts is very marked with nine districts having half their rural population living further than 10 kilometres from a primary school (see Table 2) - Pinetown, Alfred, Port Shepstone, Ixopo, Kranskop, Bergville, Klip River, Utrecht and Eshowe. Seven census districts however, have only 10 per cent or less of their rural population more than 10 kilometres from a primary school Inanda, Lower Tugela, Pietermaritzburg, Lion's River, Mooi River, New Hanover and Babanango. In most of the urban areas virtually all the children aged 5-15 years live within 10 kilometres of a school, and only in Port Shepstone, Kranskop, Eshowe and Mtunzini (all with a very small urban school going population) are over 90 per cent further than 10 kilometres from a primary school. It must be reiterated, however, that 10 kilometres is a considerable distance to walk to school. Thus, even in urban areas access may not really be adequate.

22 Using the figures in the 1986 DET annual report (which includes two Transvaal circuits) the percentage is 13,0 . The percentage for KwaZulu, from the annual report is 20 per cent. The numbers in the text exclude DET schools in KwaZulu, the Transvaal and Inanda Released Area 33.

23 Umzinto, Alfred, Underberg, Kranskop, Newcastle, Babanango, Hlabisa, Utrecht, Eshowe and Mtunzini.

Lower Tugela, Camperdown, Port Shepstone, Lion's River, Richmond, Mooi River, Impendle, Bergville, Weenen, Dannhauser, Éstcourt, Ngotshe, Paulpietersburg and Mtonjanani.

Farm schools have only recently been allowed Standards 6 and 7 and are most unlikely to be granted permission to go higher.

This figure is arrived at by comparing the 1985 (adjusted) $5-15$ year population per census district with the 1985 DET school enrolment of schools within that census district. 
27 It has been found for example (RIEP, 1986, p. 15) that 62 per cent of the black pupils in Standard 6 (in South Africa as a whole) were 15 years and older, and only 34 per cent were aged 13 and 14 years (the age at which most pupils would be in Standard 6 in white schools).

In certain areas (Inanda and Impendle) more than 100 per cent of the children are at school - this would appear to be the result of children attending school from neighbouring KwaZulu areas, or possibly of the adjustment for undercount in the 1985 census being inadequate.

29 It was estimated (RIEP, 1986, p. 5) that 36,6 per cent of black children in the 5-19 age group in 1986 were not in school. Therefore it appears that in Natal, the percentage not in school (52 per cent of the 5-15 age group in 1985) is higher than average.

30 This would appear to be less of a problem in rural schools, particularly at the junior primary level where an excess of pupils can be accommodated by holding classes out of doors.

31 Case studies have revealed instances of parents hiring other children to provide labour for the farmer, so enabling their child to continue its schooling. Poverty would often preclude such a possibility, however.

32 Refer to the last footnote of 3.1 for a discussion of the length of schooling necessary for functional literacy.

33 Table 5 shows the data under discussion divided into urban and rural areas. This shows quite clearly the educational superiority of the urban areas (whether because of migration or because of the presence of secondary schools). The only rural areas with over 30 per cent of this age cohort with a secondary education are the rural populations of Pinetown, Polela and Bergville. The data available for this study has precluded the type of assessment using qualitative data which may show that a school with a particularly good reputation and record attracts and retains larger numbers of children than a less highly regarded school. Polela secondary school for instance is said to have a good reputation.

34 In 17 of the 38 census districts less than 20 per cent of the 20-24 age cohort have any secondary education whatsoever.

Lower Tugela, Umzinto, Underberg, Kranskop, New Hanover, Richmond, Umvoti, Impendle, Weenen, Utrecht, Babanango, Ngotshe, Paulpietersburg, Eshowe, Lower Umfolosi, Mtonjaneni and Mtunzini.

35 A study of the relative numbers of males and females at various levels of education (Department of Education and Training Annual Report, 1986, p. 261-262) show that there are marginally more girls than boys at the higher levels of education but insufficient to make the percentage of females with secondary education much different to the overall percentage.

36 See also Wood (1988) for the relationship between literacy and infant mortality.

37 A problem here is the different demographic profiles of the various groups (15 per cent of whites are aged 9 and under as opposed to 21 per cent of blacks in Natal) but this is not sufficient to account for the great discrepancy in education levels. 
39 This includes those who are still too young to have any education.

40 This comparison is of interest since the percentage of blacks too young to be in school is greater in KwaZulu than Natal, whereas the percentage with no education is somewhat greater in Natal than in KwaZulu.

41 Nasson (1988, p. 18-9) argues that this is intentional and that the provision of farm schools is intended by farmers to provide a minimal level of literacy for their workforce and not to 'educate' them in the broader sense of the word.

42 This does not include those with a post Std. 10 qualification. 
27 It has been found for example (RIEP, 1986, p. 15) that 62 per cent of the black pupils in Standard 6 (in South Africa as a whole) were 15 years and older, and only 34 per cent were aged 13 and 14 years (the age at which most pupils would be in Standard 6 in white schools).

28 In certain areas (Inanda and Impendle) more than 100 per cent of the children are at school - this would appear to be the result of children attending school from neighbouring KwaZulu areas, or possibly of the adjustment for undercount in the 1985 census being inadequate.

29 It was estimated (RIEP, 1986, p. 5) that 36,6 per cent of black children in the 5-19 age group in 1986 were not in school. Therefore it appears that in Natal, the percentage not in school (52 per cent of the 5-15 age group in 1985) is higher than average.

30 This would appear to be less of a problem in rural schools, particularly at the junior primary level where an excess of pupils can be accommodated by holding classes out of doors.

31 Case studies have revealed instances of parents hiring other children to provide labour for the farmer, so enabling their child to continue its schooling. Poverty would often preclude such a possibility, however.

32 Refer to the last footnote of 3.1 for a discussion of the length of schooling necessary for functional literacy.

33 Table 5 shows the data under discussion divided into urban and rural areas. This shows quite clearly the educational superiority of the urban areas (whether because of migration or because of the presence of secondary schools). The only rural areas with over 30 per cent of this age cohort with a secondary education are the rural populations of Pinetown, Polela and Bergville. The data available for this study has precluded the type of assessment using qualitative data which may show that a school with a particularly good reputation and record attracts and retains larger numbers of children than a less highly regarded school. Polela secondary school for instance is said to have a good reputation.

34 In 17 of the 38 census districts less than 20 per cent of the 20-24 age cohort have any secondary education whatsoever.

Lower Tugela, Umzinto, Underberg, Kranskop, New Hanover, Richmond, Umvoti, Impendle, Weenen, Utrecht, Babanango, Ngotshe, Paulpietersburg, Eshowe, Lower Umfolosi, Mtonjaneni and Mtunzini.

35 A study of the relative numbers of males and females at various levels of education (Department of Education and Training Annual Report, 1986, p. 261-262) show that there are marginally more girls than boys at the higher levels of education but insufficient to make the percentage of females with secondary education much different to the overall percentage.

36 See also Wood (1988) for the relationship between literacy and infant mortality.

37 A problem here is the different demographic profiles of the various groups (15 per cent of whites are aged 9 and under as opposed to 21 per cent of blacks in Natal) but this is not sufficient to account for the great discrepancy in education levels. 
39 This includes those who are still too young to have any education.

40 This comparison is of interest since the percentage of blacks too young to be in school is greater in KwaZulu than Natal, whereas the percentage with no education is somewhat greater in Natal than in KwaZulu.

41 Nasson (1988, p. 18-9) argues that this is intentional and that the provision of farm schools is intended by farmers to provide a minimal level of literacy for their workforce and not to 'educate' them in the broader sense of the word.

42 This does not include those with a post Std. 10 qualification. 

primary schoole in Natal censene districts'

\begin{tabular}{|c|c|c|c|c|c|}
\hline \multirow{2}{*}{ Census districts } & \multirow{2}{*}{ Population $^{2}$} & \multicolumn{2}{|c|}{$\begin{array}{l}\text { Over } 10 \mathrm{~km} \text { from } \\
\text { primary school }\end{array}$} & \multicolumn{2}{|c|}{$\begin{array}{l}\text { Over } 5 \mathbf{k m} \\
\text { from JP }\end{array}$} \\
\hline & & Numbers & Percentage & Numbers & Percentage \\
\hline Durban " & 7730 & 0 & 0,0 & 0 & 0.0 \\
\hline Inanda & 3667 & 0 & 0.0 & 0 & 0.0 \\
\hline Pinetown & 8542 & 2566 & 30.0 & 2968 & 34.7 \\
\hline Lower Tugela & 19836 & 209 & 1.1 & 7669 & 38,7 \\
\hline Camperdown & 4944 & 1081 & 21.9 & 1870 & 37.8 \\
\hline Pictermaritzburg & 16471 & 123 & 0.7 & 838 & 5,1 \\
\hline Umzinto & 4196 & 531 & 12.7 & 815 & 19.4 \\
\hline Alfred & 1881 & 963 & 51.2 & 631 & 33.5 \\
\hline Port Shepstone & 2824 & 1929 & 68.3 & 1305 & 46.2 \\
\hline Mt Currie & 8255 & 2105 & 25.5 & 1250 & 15.1 \\
\hline Polela & 1355 & 473 & 34.9 & 1035 & 76.4 \\
\hline Underberg & 2064 & 828 & 40.1 & 819 & 39.7 \\
\hline Ixopo & 7975 & 4506 & 56.5 & 3839 & 48,1 \\
\hline Kranskop & 1505 & 1064 & 70.7 & 340 & 22.6 \\
\hline Lion's River & 7790 & 153 & 2,0 & 430 & 5.5 \\
\hline New Hanover & 9466 & 0 & 0.0 & 355 & 3.8 \\
\hline Richmond & 4646 & 1144 & 24.6 & 957 & 20,6 \\
\hline Umvoti & 8912 & 1103 & 12.4 & 885 & 9.9 \\
\hline Mooi River & 6205 & 95 & 1.5 & 493 & 7.9 \\
\hline Impendle & 1444 & 442 & 30.6 & 964 & 66.8 \\
\hline Bergville & 8345 & 5191 & 62.2 & 3266 & 39.1 \\
\hline Estcourt & 9541 & 4192 & 43.9 & 3706 & 38.8 \\
\hline Klipriver & 12753 & 7513 & 58.9 & 4142 & 32.5 \\
\hline Weenen & 3574 & 1096 & 30.7 & 1503 & 42.1 \\
\hline Dannhauser & 2472 & 285 & 11.5 & 769 & 31.1 \\
\hline Dundee & 6084 & 599 & 9.8 & 1130 & 18.6 \\
\hline Glencoe & 2701 & 162 & 6.0 & 379 & 14.0 \\
\hline Newcastle & 4382 & 1053 & 24.0 & 1336 & 30.5 \\
\hline Utrecht & 8621 & 5247 & 60.9 & 3188 & 37.0 \\
\hline Babanango & 4165 & 362 & 8,7 & 1225 & 29.4 \\
\hline Ngotshe & 8345 & 1805 & 21,6 & 2856 & 34,2 \\
\hline Paulpietersburg & 5549 & 949 & 17.1 & 903 & 16.3 \\
\hline Vryheid & 15561 & 1596 & 10.3 & 2802 & 18.0 \\
\hline Eshowe & 946 & 946 & 100.0 & 946 & 100.0 \\
\hline Hlabisa & 1214 & 454 & 37.4 & 625 & 51.5 \\
\hline Lower Umfolosi & 7766 & 1247 & 16.1 & 597 & 7.7 \\
\hline Mtonjaneni & 2086 & 1017 & 48.8 & 929 & 44.5 \\
\hline Mtunzini & 1566 & 789 & 50.4 & 886 & 56.6 \\
\hline NATAL & 235379 & 53818 & 22.9 & 58651 & 24.9 \\
\hline
\end{tabular}

Census districts closeiy approximate magisterial districts.

1. This is purely physlcal access. other obstacles to access Include topography. farmers refusIng to enrol nelghbouring children. poverty and the economic role that chlidren may be re. quired to play at home

Schools located on map according to information prov lded by the Department of Education and Training.

A 10-kilometre walk to and from school dally is a very long way. The Department of Education and Training recognises that Ideally no child should reside further than $10 \mathrm{~km}$ from a school.

2. From the 1985 census. adjusted for under-enumeration. 


\begin{tabular}{|c|c|c|c|c|c|c|}
\hline \multirow[b]{2}{*}{ Census districts } & \multicolumn{3}{|c|}{ URBAN } & \multicolumn{3}{|c|}{ RURAL } \\
\hline & $\begin{array}{l}\text { Population } 2 \\
\text { Aged 5-15 }\end{array}$ & $\begin{array}{l}\text { Over } 10 \mathrm{~km} \text { from } \\
\text { primary school } \\
\text { Percentage }\end{array}$ & $\begin{array}{l}\text { Over } 5 \mathrm{~km} \\
\text { Irom JP } \\
\text { Percentage }\end{array}$ & $\begin{array}{l}\text { Population } 2 \\
\text { Aged } 5-15\end{array}$ & $\begin{array}{l}\text { Over } 10 \mathrm{~km} \text { from } \\
\text { primary school } \\
\text { Percentage }\end{array}$ & $\begin{array}{l}\text { Over } 5 \mathrm{~km} \\
\text { from JP } \\
\text { Percentage }\end{array}$ \\
\hline Durban & 7730 & 0.0 & 0.0 & & & \\
\hline Inanda & 1731 & 0.0 & 0.0 & 1936 & 0.0 & 0.0 \\
\hline Pinelown & 5776 & 0.0 & $50.0^{\circ}$ & 2766 & 92.8 & 2.9 \\
\hline Lower Tugela & 912 & 0.0 & 0.0 & 18924 & 1.1 & 40.5 \\
\hline Camperdown & 310 & 0.0 & 9.7 & 4634 & 23.3 & 39.7 \\
\hline Pietermaritzburg & 13356 & 0.0 & 0.0 & 3115 & 3.9 & 26.9 \\
\hline Umzlnto & 265 & 20.8 & 43,0 & 3981 & 12.0 & 17.6 \\
\hline Allred & 35 & 0.0 & 0.0 & 1846 & 52,2 & 34,2 \\
\hline Port Shepstone & 191 & 98.4 & 83.8 & 2633 & 66.1 & 43.5 \\
\hline Mt Curric & 1709 & 0,0 & 0.0 & 6546 & 32,2 & 19.1 \\
\hline Polela & 6 & 0,0 & 0.0 & 1349 & 35.1 & 76.7 \\
\hline Underberg & 21 & 0.0 & 0.0 & 2043 & 40.5 & 40.1 \\
\hline Lopo & 31 & 0.0 & 0,0 & 7944 & 56.7 & 48.3 \\
\hline Kranskop & 10 & 100.0 & 0,0 & I 495 & 70,5 & 22.7 \\
\hline Lion's River & 409 & 0,0 & 0.0 & 7381 & 2.1 & 5.8 \\
\hline New Hanover & 1540 & 0.0 & 0,0 & 7926 & 0.0 & 4.5 \\
\hline Richmond & 142 & 0.0 & 0.0 & 4504 & 25.4 & 21.2 \\
\hline Umvoti & 1286 & 0.0 & 0.0 & 7626 & 14,5 & 11.6 \\
\hline Mool River & 992 & 0.0 & 0,0 & 5213 & 1.8 & 9.5 \\
\hline Impendle & & & & 1444 & 30.6 & 66,8 \\
\hline Bergville & 6 & 0.0 & 0,0 & 8339 & 62.2 & 39.2 \\
\hline Estcourt & 911 & 0,0 & 0.0 & 8630 & 48,6 & 42.9 \\
\hline Kliprtver & 2949 & 0,0 & 50.0 & 9804 & 76.6 & 27.2 \\
\hline Weenen & 725 & 0.0 & 0.0 & 2849 & 38.5 & 52.8 \\
\hline Dannhauser & 278 & 0.0 & 0.0 & 2194 & 13.0 & 35.1 \\
\hline Dundee & 1983 & 0.0 & 0.0 & 4101 & 14,6 & 27.6 \\
\hline Glencoe & 1338 & 0.0 & 0.0 & 1363 & 11.9 & 27.8 \\
\hline Newcastle & 54 & 0,0 & 42.6 & 4328 & 24.3 & 30.3 \\
\hline Utrecht & 206 & 0,0 & 50,0 & 8415 & 62.4 & 36.7 \\
\hline Babanango & & & & 4165 & 8.7 & 29.4 \\
\hline Ngotshe & 554 & 0.0 & 0.0 & 7791 & 23.2 & 36.7 \\
\hline Paulpietersburg & 971 & 0,0 & 0.0 & 4578 & 20.7 & 19.7 \\
\hline Vryheid & 1771 & 0.0 & 0.0 & 13790 & 11.6 & 20,3 \\
\hline Eshowe & $13 !$ & 100.0 & 100,0 & 815 & 100,0 & 100.0 \\
\hline Hlabisa & 45 & 0.0 & 15.6 & 1169 & 38.8 & 52.9 \\
\hline Lower Um[o]osi & 520 & 36,5 & 16.2 & 7246 & 14.6 & 7.1 \\
\hline Mtonjaneni & 135 & 45,9 & 100.0 & 1951 & 48.9 & 41.6 \\
\hline Mtunzini & 123 & 91,9 & 95.9 & 1443 & 46,8 & 53.2 \\
\hline NATAL & 49152 & 1.5 & 10,7 & 186277 & 28.5 & 28.7 \\
\hline
\end{tabular}

Census districts closely approximate magisterial districts.

1. This is purely physical access. other obstacles to access Include topography. farmers refusIng to enrol neighbouring children. poverty and the economic role that children may be required to play at home.

Schools located on map according to Information provided by the Department of Education and Tralning.

A 10-kilometre walk to and from school dally is a very long way. The Department of EducatIon and Training recognises that Ideally no child should reside further than $10 \mathrm{~km}$ from a school.

2. From the 1985 census. adjusted for under-enumeration. 

Kwazula schools in Natal $)^{2}$

\begin{tabular}{|c|c|c|c|c|c|c|c|}
\hline Census districts & $\begin{array}{c}\text { Aged } \\
5-15^{3}\end{array}$ & $\begin{array}{c}\text { Class } 1 \\
\text { to Std } 5\end{array}$ & $\begin{array}{l}\text { Class } 1 \\
\text { to Sid } 8\end{array}$ & $\begin{array}{c}\text { Std } \\
6-10\end{array}$ & $\begin{array}{l}\text { In Class } 1 \\
\text { to Std } 5\end{array}$ & $\begin{array}{c}\text { In Class } 1 \\
\text { to Std } 8\end{array}$ & $\begin{array}{l}\text { Percentage } \\
\text { secondary of } \\
\text { primary }\end{array}$ \\
\hline Durban & 7731 & 5149 & 6273 & 1815 & 66.6 & 81.1 & 35.2 \\
\hline Inanda & 3621 & 3819 & 4638 & 1123 & 105,5 & 128.1 & 29.4 \\
\hline Pinetown & 8543 & 7015 & 8440 & 1543 & 82.1 & 98,8 & 22,0 \\
\hline Lower Tugela & 19836 & 11741 & 13302 & 1986 & 59.2 & 67.1 & 16.9 \\
\hline Camperdown & 4944 & 1509 & 1533 & 24 & 30,5 & 31,0 & 1.6 \\
\hline Pletermaritzburg & 16471 & 10698 & 13746 & 4478 & 65,0 & 83.5 & 41.9 \\
\hline Umzinto & 4246 & 1377 & 1377 & 0 & 32.4 & 32,4 & 0,0 \\
\hline Alfred & 1881 & 1902 & 1902 & 0 & 101,1 & 101,1 & 0,0 \\
\hline Port Shepstone & 2824 & 4026 & 4102 & 76 & 142,6 & 145,3 & 1.9 \\
\hline Mt Currie & 8225 & 5406 & 5630 & 276 & 65,7 & 68.4 & 5.1 \\
\hline Polela & 1355 & 1755 & 2044 & 403 & 129,5 & 150,8 & 23,0 \\
\hline Underberg & 2064 & 1338 & 1338 & 0 & 64.8 & 64,8 & 0.0 \\
\hline Ixopo & 7975 & 6165 & 6569 & 140 & 77.3 & 82,4 & 2,3 \\
\hline Kranskop & 1505 & 3159 & 3315 & 156 & 209.9 & 220,3 & 4,9 \\
\hline Lion's Rlver & 7519 & 5388 & 6007 & 619 & 71.7 & 79.9 & 11.5 \\
\hline New Hanover & 9466 & 5785 & 6219 & 476 & 61.1 & 65.7 & 8,2 \\
\hline Richmond & 4646 & 8287 & 9422 & 2136 & 178.4 & 202,8 & 25,8 \\
\hline Umvotl & 8913 & 6037 & 6758 & 1011 & 67.7 & 75.8 & 16.7 \\
\hline Mooi River & 6206 & 3762 & 4231 & 542 & 60.6 & 68,2 & 14.4 \\
\hline Impendle & 1444 & 1296 & 1421 & 125 & 89.8 & 98.4 & 9.6 \\
\hline Bergville & 8345 & 5643 & 6417 & 908 & 67.6 & 76.9 & 16,1 \\
\hline Estcourt & 9541 & 7385 & 8016 & 754 & 77.4 & 84,0 & 10.2 \\
\hline Klipriver & 12753 & 7272 & 8168 & 1031 & 57,0 & 64.0 & 14.2 \\
\hline Weenen & 3574 & 943 & 984 & 41 & 26.4 & 27,5 & 4,3 \\
\hline Dannhauser & 2471 & 1530 & 1584 & 54 & 61.9 & 64.1 & 3,5 \\
\hline Dundee & 6084 & 3552 & 4078 & 679 & 58.4 & 67.0 & 19.1 \\
\hline Glencoe & 2700 & 1789 & 2033 & 284 & 66,3 & 75,3 & 15,9 \\
\hline Newcastle & 4381 & 3248 & 3271 & 23 & 74.1 & 74.7 & 0.7 \\
\hline Utrecht & 8621 & 3847 & 3847 & 0 & 44,6 & 44.6 & 0.0 \\
\hline Babanango & 4165 & 1962 & 1962 & 0 & 47.1 & 47.1 & 0.0 \\
\hline Ngotshe & 8345 & 4247 & 4432 & 185 & 50.9 & 53.1 & 4,4 \\
\hline Paulpletersburg & 5549 & 3572 & 3766 & 194 & 64.4 & 67.9 & 5.4 \\
\hline Vryheid & 15561 & 10195 & 11576 & 1749 & 65.5 & 74,4 & 17.2 \\
\hline Eshowe & 946 & 0 & 0 & 0 & 0.0 & 0,0 & 0.0 \\
\hline Hlabisa & 1214 & 679 & 679 & 0 & 55.9 & 55.9 & 0.0 \\
\hline Lower Umfolos! & 7766 & 5322 & 6465 & 1310 & 68,0 & B2.7 & 24.8 \\
\hline Mtonjaneni & 2086 & 1100 & 1178 & 78 & 52.7 & 56.5 & 7,1 \\
\hline Mtunzinl & 1565 & 2004 & 2271 & 490 & 128.1 & 145,1 & 24.5 \\
\hline NATAL & 235082 & 159904 & 178994 & 17825 & 68.0 & 76.1 & 15.5 \\
\hline INANDA 33 & & 4806 & 5878 & 1292 & & & 26.9 \\
\hline
\end{tabular}

Census districts closely approximate magisterial districts.

1. Based on figures for each school in 1985 supplied by the Department of Education and TrainIng. apportioned to relevant census districts on the basis of census district maps.

2. KwaZulu schools in Natal appear to be largely on South African Development Trust land not yet transferred to KwaZulu, but are In areas enumerated as Natal In the 1985 census.

3. From the 1985 census. adjusted for under-enumeration. 
Table 4 - Education levels of the black 20-24 age group ${ }^{1}$ In Natal census dintricte

\begin{tabular}{|c|c|c|c|c|c|c|c|c|}
\hline \multirow[b]{2}{*}{ Census districts } & \multirow[b]{2}{*}{ Total $^{2}$} & \multicolumn{4}{|c|}{ Numbers } & \multicolumn{3}{|c|}{ Percentage } \\
\hline & & $\begin{array}{c}\text { Std } 1 \\
\& \text { under }\end{array}$ & $\begin{array}{c}\text { Std } \\
2-5\end{array}$ & $\begin{array}{l}\text { Std } \\
6-10\end{array}$ & $\begin{array}{l}\text { Post } \\
\text { school }\end{array}$ & $\begin{array}{l}\text { Std l } \\
\text { \& under }\end{array}$ & $\begin{array}{l}\text { Std } \\
2-5\end{array}$ & $\begin{array}{l}\text { Std } 6 \\
\text { \& over }\end{array}$ \\
\hline Durban & 8234 & 940 & 2584 & 4586 & 124 & 11 & 31 & 57 \\
\hline Inanda & 2593 & 866 & 855 & 844 & 28 & 33 & 33 & 34 \\
\hline Plnetown & 4925 & 760 & 1826 & 2286 & 53 & 15 & 37 & 47 \\
\hline Lower Tugela & 8351 & 3070 & 2825 & 2436 & 20 & 37 & 34 & 29 \\
\hline Camperdown & 2612 & 1016 & 1103 & 482 & 11 & 39 & 42 & 19 \\
\hline Pietermaritzburg & 7479 & 1093 & 1876 & 4389 & 121 & 15 & 25 & 60 \\
\hline UmzInto & 2264 & 1141 & 784 & 336 & 3 & 50 & 35 & 15 \\
\hline Alfred & 587 & 175 & 229 & 178 & 5 & 30 & 39 & 31 \\
\hline Port Shepstone & 2062 & 812 & 745 & 495 & 10 & 39 & 36 & 24 \\
\hline Mt Currie & 2209 & 573 & 994 & 621 & 21 & 26 & 45 & 29 \\
\hline Polela & 339 & 83 & 147 & 107 & 2 & 24 & 43 & 32 \\
\hline Underberg & 790 & 278 & 356 & 155 & 1 & 35 & 45 & 20 \\
\hline Lxopo & 2188 & 769 & 907 & 466 & 46 & 35 & 41 & 23 \\
\hline Kranskop & 705 & 370 & 253 & 82 & 0 & 52 & 36 & 12 \\
\hline Lion's River & 2427 & 651 & 1164 & 594 & 18 & 27 & 48 & 25 \\
\hline New Hanover & 3277 & 1418 & 1193 & 660 & 6 & 43 & 36 & 20 \\
\hline Richmond & 2081 & 929 & 772 & 371 & 9 & 45 & 37 & 18 \\
\hline Umvoti & 3300 & 1596 & 1084 & 602 & 18 & 48 & 33 & 19 \\
\hline Mool River & 1790 & 516 & 773 & 495 & 6 & 29 & 43 & 28 \\
\hline Impendle & 385 & 148 & 176 & 60 & 1 & 38 & 46 & 16 \\
\hline Bergville & 1505 & 342 & 646 & 504 & 13 & 23 & 43 & 34 \\
\hline Estcourt & 2426 & 861 & 1025 & 536 & 4 & 35 & 42 & 22 \\
\hline Klipriver & 3272 & 792 & 1341 & 1117 & 22 & 24 & 41 & 35 \\
\hline Weenen & 691 & 448 & 165 & 78 & 0 & 65 & 24 & 11 \\
\hline Dannhauser & 1894 & 740 & 759 & 394 & 1 & 39 & 40 & 21 \\
\hline Dundee & 2008 & 582 & 744 & 679 & 3 & 29 & 37 & 34 \\
\hline Glencoe & 886 & 218 & 382 & 282 & 4 & 25 & 43 & 32 \\
\hline Newcastle & 1591 & 419 & 792 & 373 & 7 & 26 & 50 & 24 \\
\hline Utrecht & 2473 & 1009 & 1136 & 327 & 1 & 41 & 46 & 13 \\
\hline Babanango & 709 & 285 & 316 & 107 & 1 & 40 & 45 & 15 \\
\hline Ngotshe & 2230 & 1232 & 784 & 214 & 0 & 55 & 35 & 10 \\
\hline Paulpletersburg & 1508 & 563 & 676 & 265 & 4 & 37 & 45 & 18 \\
\hline Vryheid & 6096 & 2367 & 2305 & 1390 & 34 & 39 & 38 & 23 \\
\hline Eshowe & 1300 & 689 & 416 & 189 & 6 & 53 & 32 & 15 \\
\hline Hlabisa & 3532 & 1533 & 1257 & 739 & 3 & 43 & 36 & 21 \\
\hline Lower Umfolosi & 2082 & 1164 & 608 & 306 & 4 & 56 & 29 & 15 \\
\hline Mtonjaneni & 1514 & 807 & 420 & 286 & 1 & 53 & 28 & 19 \\
\hline Mtunzini & 1549 & 885 & 445 & 217 & 2 & 57 & 29 & 14 \\
\hline NATAL & 95864 & 32140 & 34863 & 28248 & 613 & 34 & 36 & 30 \\
\hline
\end{tabular}

Census districts closely approximate magisterial districts.

1. From the 1985 census (unpublished data). It should be noted that the fact that people in these census districts have a certaln level of education does not necessarily mean they obtained it in that area. They may have moved after completing thelr education.

2. Population based on 1985 census. 
Table 5 - Education levels of the arban and raral black 20-24 age group' in Natal census districts.

\begin{tabular}{|c|c|c|c|c|c|c|c|c|}
\hline \multirow{3}{*}{ Census districts } & \multicolumn{4}{|c|}{ Urben } & \multicolumn{4}{|c|}{ Roral } \\
\hline & \multirow[b]{2}{*}{ Total $^{2}$} & \multicolumn{3}{|c|}{ Percentage } & \multirow[b]{2}{*}{ Total $^{2}$} & \multicolumn{3}{|c|}{ Percentage } \\
\hline & & $\begin{array}{c}\text { Std I } \\
\& \text { under }\end{array}$ & $\begin{array}{l}\text { Std } \\
2-5\end{array}$ & $\begin{array}{l}\text { Std } 6 \\
\text { \& over }\end{array}$ & & $\begin{array}{c}\text { Std } 1 \\
\& \text { under }\end{array}$ & $\begin{array}{l}\text { Std } \\
2-5\end{array}$ & $\begin{array}{l}\text { Std } 6 \\
\text { \& over }\end{array}$ \\
\hline Durban & 8234 & 11 & 31 & 57 & 0 & $\mathbf{0}$ & 0 & 0 \\
\hline Inanda & 1243 & 22 & 32 & 46 & 1350 & 44 & 34 & 22 \\
\hline Pinetown & 4080 & 15 & 36 & 49 & 845 & 19 & 43 & 38 \\
\hline Lower Tugela & 735 & 29 & 34 & 36 & 7616 & 37 & 34 & 29 \\
\hline Camperdown & 314 & 31 & 42 & 28 & 2298 & 40 & 42 & 18 \\
\hline Pietermarltzburg & 6347 & 11 & 22 & 67 & 1132 & 33 & 44 & 24 \\
\hline Umzinto & 425 & 36 & 39 & 24 & 1839 & 54 & 34 & 13 \\
\hline Alfred & 129 & 25 & 19 & 56 & 458 & 31 & 45 & 24 \\
\hline Port Shepstone & 713 & 22 & 38 & 40 & 1349 & 49 & 35 & 16 \\
\hline Mt Currie & 748 & 10 & 31 & 59 & 1461 & 34 & 52 & 14 \\
\hline Polela & 31 & 13 & 42 & 45 & 308 & 26 & 44 & 31 \\
\hline Underber 8 & 136 & 24 & 40 & 35 & 654 & 37 & 46 & 17 \\
\hline Ixopo & 142 & 24 & 30 & 46 & 2046 & 36 & 42 & 22 \\
\hline Kranskop & 52 & 21 & 52 & 27 & 653 & 55 & 35 & 10 \\
\hline Lion's River & 169 & 8 & 24 & 68 & 2258 & 28 & 50 & 22 \\
\hline New Hanover & 419 & 19 & 36 & 45 & 2858 & 47 & 37 & 17 \\
\hline Richmond & 83 & 27 & 41 & 33 & 1998 & 45 & 37 & 18 \\
\hline Umvoti & 742 & 17 & 35 & 48 & 2558 & 57 & 32 & 10 \\
\hline Mool River & 593 & 10 & 40 & 50 & 1197 & 38 & 45 & 17 \\
\hline Impendle & 0 & 0 & 0 & 0 & 385 & 38 & 46 & 16 \\
\hline Bergville & 43 & 33 & 42 & 26 & 1462 & 22 & 43 & 35 \\
\hline Estcourt & 574 & 22 & 44 & 34 & 1852 & 40 & 42 & 19 \\
\hline Klipriver & 1266 & 16 & 34 & 50 & 2006 & 30 & 45 & 25 \\
\hline Weenen & 206 & 50 & 31 & 18 & 485 & 71 & 21 & 8 \\
\hline Dannhauser & 130 & 10 & 35 & 55 & 1764 & 41 & 40 & 18 \\
\hline Dundee & 1090 & 15 & 32 & 53 & 918 & 46 & 43 & 11 \\
\hline Glencoe & 423 & 10 & 39 & 51 & 463 & 38 & 46 & 16 \\
\hline Newcastle & 422 & 22 & 49 & 29 & 1169 & 28 & 50 & 22 \\
\hline Utrecht & 217 & 38 & 41 & 22 & 2256 & 41 & 46 & 12 \\
\hline Babanango & 0 & 0 & 0 & 0 & 709 & 40 & 45 & 15 \\
\hline Ngotshe & 93 & 32 & 32 & 35 & 2137 & 56 & 35 & 8 \\
\hline Paulpietersburg & 320 & 16 & 41 & 43 & 1188 & 43 & 46 & 11 \\
\hline Vryheid & 1029 & 17 & 33 & 50 & 5067 & 43 & 39 & 18 \\
\hline Eshowe & 424 & 32 & 36 & 32 & 876 & 63 & 30 & 7 \\
\hline Hlablsa & 381 & 20 & 36 & 44 & 3151 & 46 & 36 & 18 \\
\hline Lower Umfolosl & 912 & 49 & 33 & 19 & 1170 & 62 & 27 & 12 \\
\hline Mtonjanenl & 221 & 25 & 44 & 31 & 1293 & 58 & 25 & 17 \\
\hline Mtunzinl & 276 & 48 & 26 & 26 & 1273 & 59 & 29 & 12 \\
\hline NATAL & 33362 & 17 & 32 & 51 & 62502 & 42 & 39 & 19 \\
\hline
\end{tabular}

Census districts closely approximate magisterial districts.

1. From the 1985 census (unpublished data). It should be noted that the fact that people in these census districts have a certaln level of education does not necessarily mean they obtained it in that area. They may have moved after completing their education.

2. Population based on 1985 census. 
Table 6 - Edncation levele of all 'races' in Natal In percentages'

\begin{tabular}{|c|c|c|c|c|c|c|c|c|c|c|c|c|}
\hline & $\begin{array}{c}\text { No } \\
\text { education }\end{array}$ & $\begin{array}{l}\text { Under } \\
\text { Std } 4\end{array}$ & & Std 5 & Std 6 & Std 7 & Std 8 & Std 9 & Std 10 & $\begin{array}{r}\text { Diplorna } \\
+ \text { Std } 9\end{array}$ & $\begin{array}{l}\text { Diploma } \\
+ \text { Std } 10\end{array}$ & Degree \\
\hline Black & & & . & & & & & & & & & \\
\hline Natal & 42.8 & 29.0 & 6,6 & 6,0 & 5.2 & 3.1 & 3.4 & 1.4 & 1.4 & 0.2 & 0,2 & 0,0 \\
\hline \multicolumn{13}{|l|}{ Coloured } \\
\hline Natal & 17,5 & 17,5 & 5.7 & 8,2 & 16.7 & 10.2 & 11.0 & 4,0 & 4.9 & 1,4 & 1.8 & 0.3 \\
\hline \multicolumn{13}{|l|}{ Indian } \\
\hline Natal & 20.2 & 17.1 & 6.0 & 7,7 & 14,1 & 6.4 & 10,0 & 5.1 & 9.1 & 0.7 & 1.9 & 1.1 \\
\hline \multicolumn{13}{|l|}{ Black } \\
\hline KwaZulu & 39.7 & 29,9 & 6.5 & 5.8 & 5.4 & 3,9 & 4.1 & 1,9 & 2,0 & 0.1 & 0.2 & 0.0 \\
\hline \multicolumn{13}{|l|}{ Black } \\
\hline \multirow[t]{2}{*}{ RSA } & 37,3 & 28.5 & 6,9 & 7.1 & 7,0 & 4,2 & 4.3 & 1.7 & 1.9 & 0.2 & 0.2 & 0.0 \\
\hline & None & -Sid 6 & Sid 6 & Std 7 & Std 8 & Std 9 & Std 10 & $\begin{array}{l}\text { Diploma } \\
\text { with } \\
\text { Std } 9\end{array}$ & $\begin{array}{l}\text { Diploma } \\
\text { with } \\
\text { Std } 10\end{array}$ & $\begin{array}{c}\text { B } \\
\text { Degree }\end{array}$ & $\begin{array}{c}\text { M } \\
\text { Degree }\end{array}$ & PHD \\
\hline \multicolumn{13}{|l|}{ White } \\
\hline Natal & 12.7 & 12,6 & 6.6 & 5.2 & 15.8 & 6,1 & 20.8 & 3.9 & 11,1 & 4,4 & 0,3 & 0,1 \\
\hline
\end{tabular}

1. Based on 1985 census report.

Thls table covers all age groups, thus groups with a high percentage of childer under 6 will have a high percentage under the heading 'No education'. 


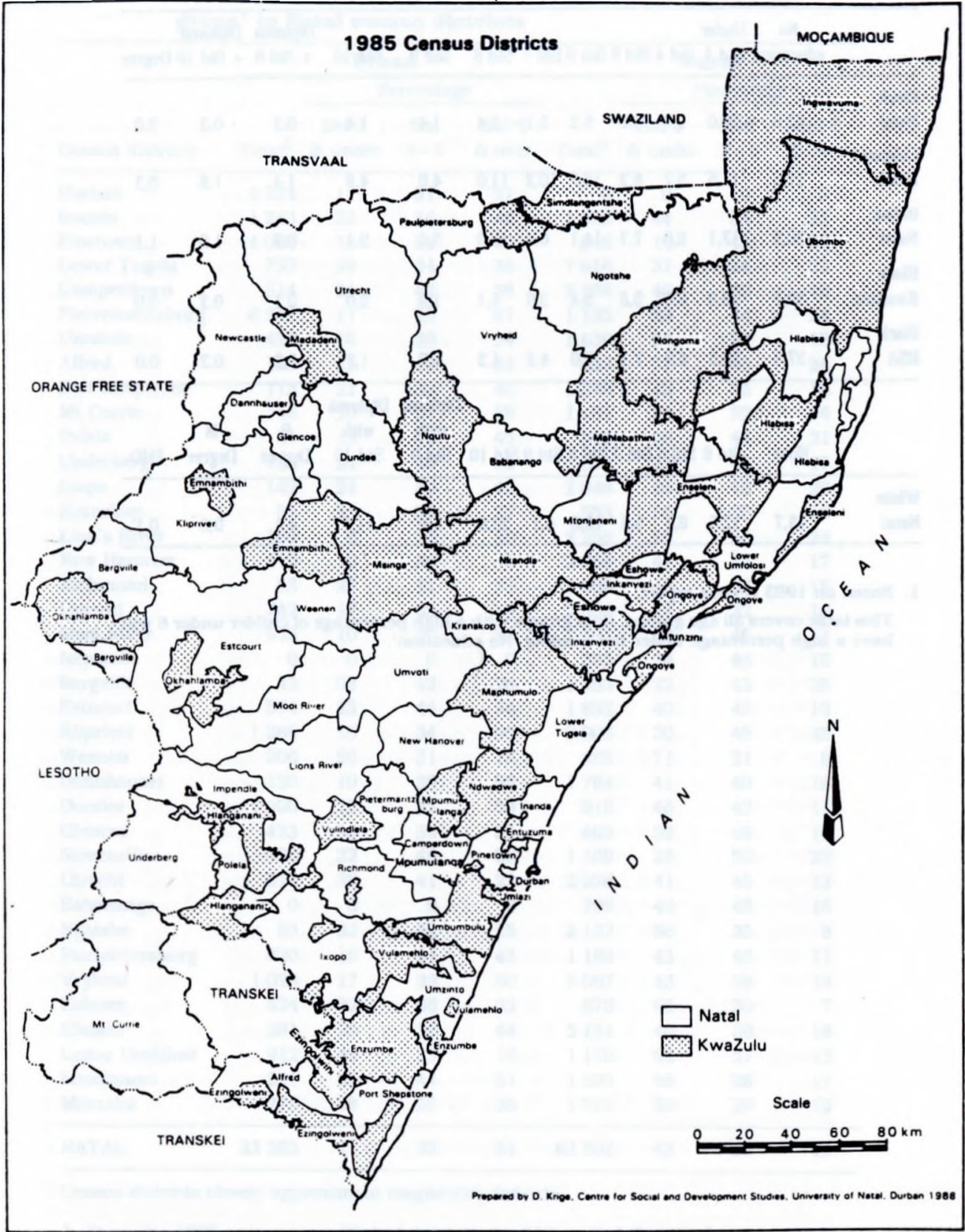




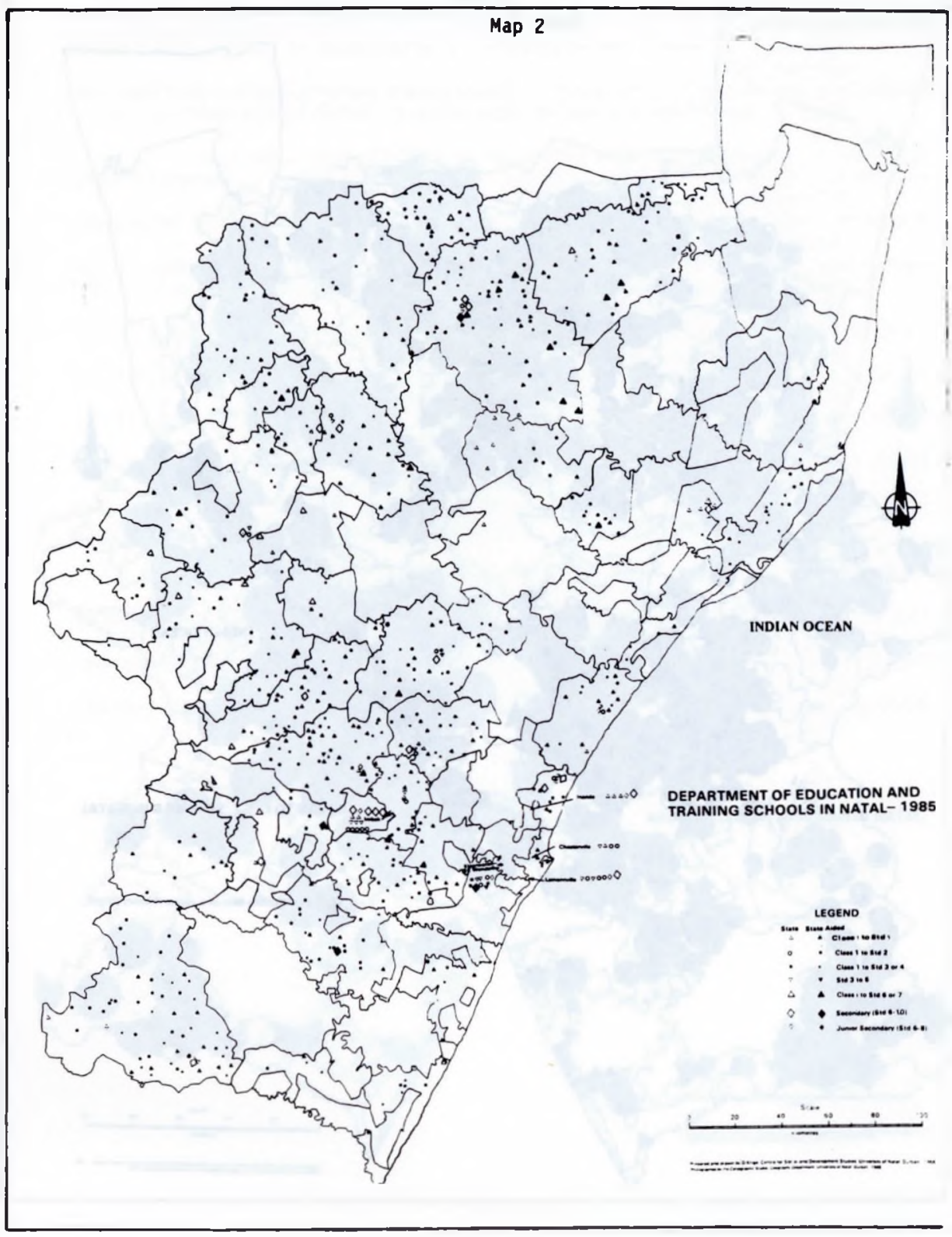




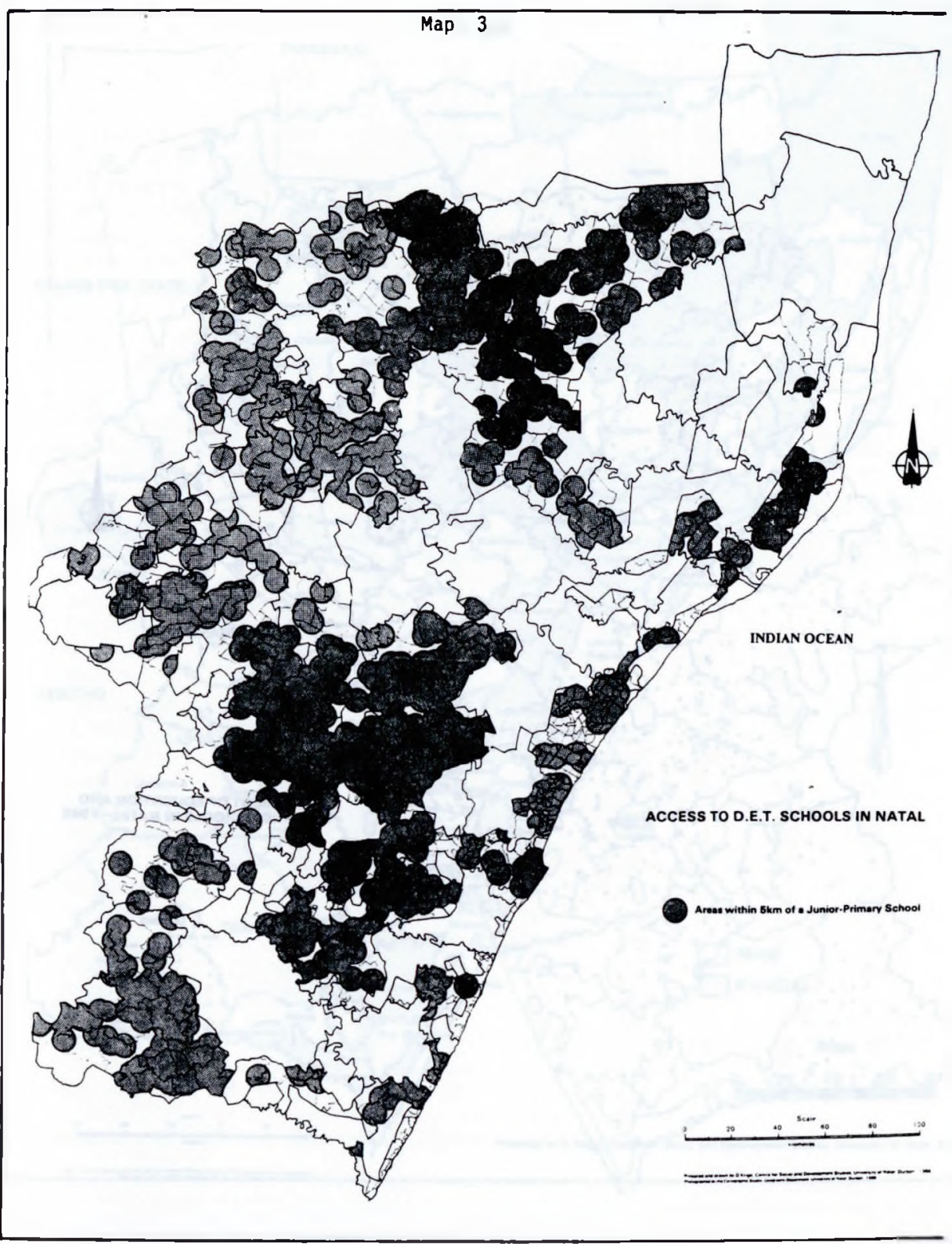




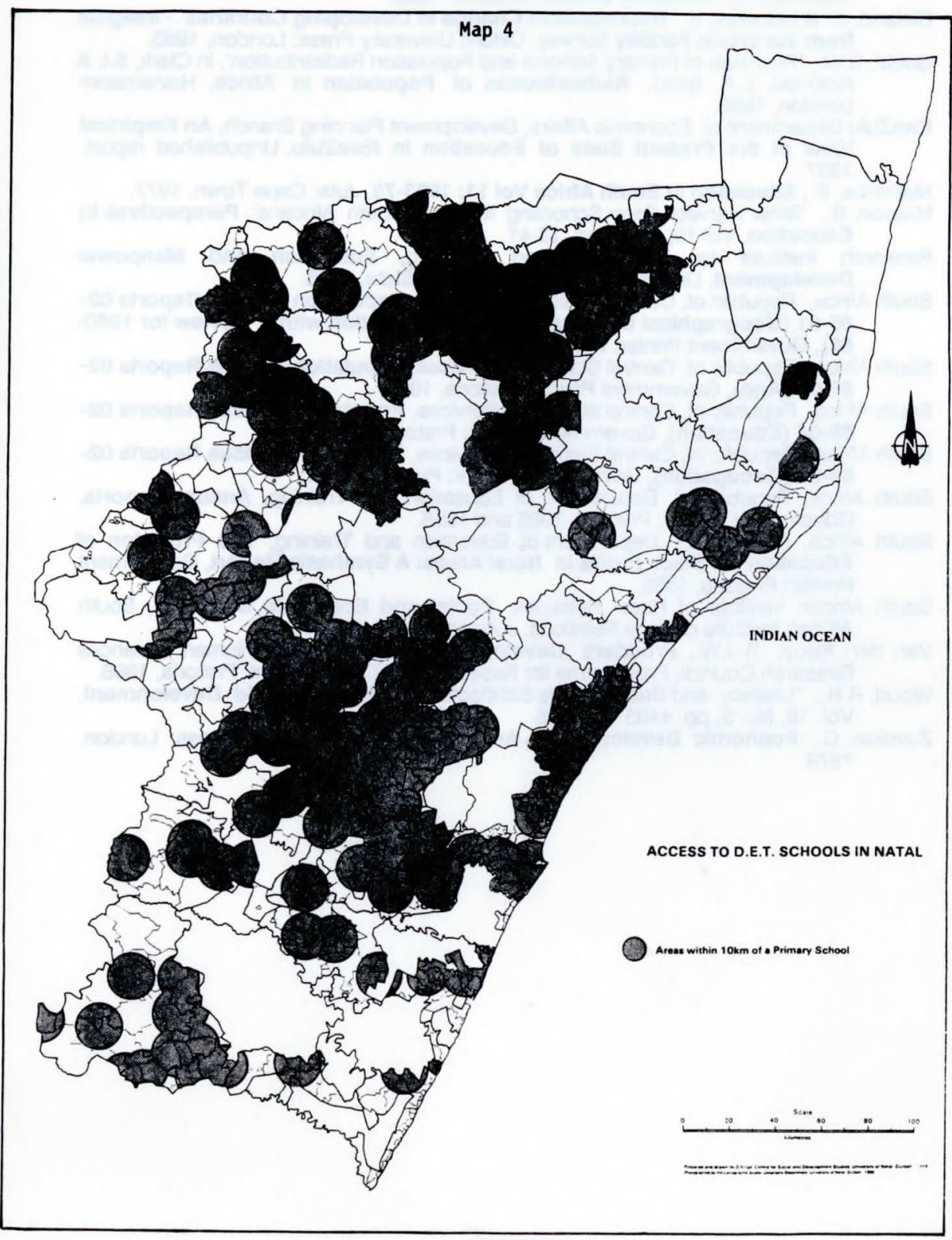




\section{REFERENCES}

Ardington, E.M., Rural Towns and Basic Needs, Rural Urban Studies Unit Working Paper No. 20, University of Natal, Durban, 1989.

Cleland, J. \& Hobcraft, J. Reproductlve Change In Developing Countrles - Insights from the World Fertility Survey, Oxford University Press: London, 1985

Gould, S.W., 'Provision of Primary Schools and Population Redistribution', in Clark, S.I. \& Kosinski, LA. (eds), Redistribution of Population in Africa, Heinemann: London, 1982.

KwaZulu Department of Economic Affairs, Development Planning Branch, An Empirical View of the Present State of Education in KwaZulu, Unpublished report, 1987.

Malherbe, E., Education in South Atrica Vol 11: 1923-75, Juta: Cape Town, 1977.

Nasson, B., 'Bitter Harvest: Farm Schooling for Black South Africans', Perspectives in Education, Vol 10, No. 1, pp. 13-41.

Research Institute for Education and Planning, Education and Manpower Development, University of the Orange Free State, 1986.

South Africa, Republic of, Central Statistical Services, Population Census Reports 0285-01 (Geographical Distribution of the Population with a Review for 196085), Government Printer: Pretoria, 1985.

South Africa, Republic of, Central Statistical Services, Population Census Reports 0285-02 (Age), Government Printer: Pretoria, 1985.

South Africa, Republic of, Central Statistical Services, Population Census Reports 0285-04 (Education), Government Printer: Pretoria, 1985.

South Africa, Republic of, Central Statistical Services, Population Census Reports 0285-05 (Occupation), Government Printer: Pretoria, 1985.

South Africa, Republic of, Department of Education and Training, Annual Reports, Government Printer: Pretoria, 1985 and 1986.

South Africa, Republic of, Department of Education and Training. The Provision of Education for Black Pupils in Rural Areas: A Synthesis Report, Government Printer: Pretoria, 1986.

South African Institute of Race Relations, Social and Economic Update 5, South African Institute of Race Relations: Johannesburg, 1988

Van der Kooy, R.J.W., Prodders Development Annual 1988, Human Sciences Research Council, Programme for Research and Development: Pretoria, 1988.

Wood, R.H., 'Literacy and Basic Needs Satisfaction in Mexico', World Development, Vol. 16, No. 3, pp. 4405-17, 1988.

Zuvekas, C., Economic Development - An Introduction, MacMillan Press: London, 1979. 


\section{(c) $(9 \odot$}

This work is licensed under a

Creative Commons

Attribution - NonCommercial - NoDerivs 3.0 License.

To view a copy of the license please see:

http://creativecommons.org/licenses/bv-nc-nd/3.0/

This is a download from the BLDS Digital Library on OpenDocs

http://opendocs.ids.ac.uk/opendocs/ 